\title{
POTENSIAL MESENCHYMAL STEM CELL-DERIVED EXTRACELLULAR VESICLES (MSC-EVS) SEBAGAI TERAPI TERBARU DALAM OBAT ISKEMIK RETINAL
}

\author{
Sisca $^{1}$,Nurul Azizah ${ }^{2}$, M.Salas Al Aldi ${ }^{3}$ \\ 1,2,3 Universitas Hasanuddin \\ e-mail: siscaifak123@gmail.com
}

\begin{abstract}
Retinal ischemia (IR) is still the biggest cause of blindness in the world. Several factors contribute to the pathogenesis of Retinal Ischemia. However, oxidative stress and inflammatory processes are the main factors. Various forms of therapy have been applied in clinical care of Retinal ischemia, but none have been optimal for repairing the cells damage and able to avoid immunological and oncogenic reactions. MSC-EVs have opened a new perspective for the treatment of Retinal Ischemia. MSC is a multipotent cell with paracrine characteristic and mediated by extracellular vesicles (EVS) which is derivative of MSC that can be used as a biomimetic agent to help nerve protection and tissue regeneration. In addition, MSC-EVs have a lower tendency to trigger immune responses and the inability to directly form tumors. Therefore, MSC EVS can prove to be an ideal source for the latest therapies in dealing with the problem of retinal ischemia.
\end{abstract}

This Literature Riview is compiled by using a literature study with collecting valid journals, particular inclusion and exclusion criteria. On testing its effectiveness, three indicators were used, that is the protective effect of $M S C-E V S$ on retinal cells, the effects of post-ischemic in vivo administration of MSC-EVs, and the distribution of MSC-EVS in humour vitreous and long-term protective effects estimates. Significantly shows a protective effect, decreases inflammatory factors and apoptosis of retinal cells. Based on the results of testing in vitro and in vivo MSC-EVs are endocytosis by retinal cells that provide neuroprotective effects before and after treatment, and this effect can be developed into long-term therapy. Therefore, using MSC-EVS can be a promising therapy in the treatment of retinal ischemia.

Keywords $\quad$ : EVs, Iskemia Retina, MSC, Sel Retina R28.

\begin{abstract}
Abstrak
Iskemia Retina (IR) masih menjadi penyebab terbesar angka kebutaan di seluruh dunia. Beberapa faktor berkontribusi terhadap patogenesis Iskemia Retina. Namun, stres oksidatif dan proses inflamasi merupakan faktor yang utama. Berbagai bentuk terapi telah diterapkan dalam perawatan klinis Iskemia Retina namun belum satu pun yang optimal untuk memperbaiki sel yang rusak dan mampu menghindari reaksi imunologis dan onkogenik. MSC-EVs telah membuka perspektif baru untuk pengobatan Iskemia Retina. MSC adalah sel multipoten dengan sifat parakrin dan dimediasi oleh Extracellular Vesicles (EVs) yang merupakan turunan MSC yang dapat digunakan sebagai agen biomimetik untuk membantu perlindungan saraf dan regenerasi jaringan. Selain itu, MSC-EVs memiliki kecenderungan yang lebih rendah untuk memicu respon imun serta ketidakmampuan untuk secara langsung membentuk tumor. Oleh karena itu, MSC-EVs dapat terbukti menjadi sumber yang ideal untuk terapi terbaru dalam mengatasi masalah iskemia retina.
\end{abstract}

Literature Riview ini disusun menggunakan metode studi pustaka dengan mengumpulkan jurnal yangvalid dengan kriteria inklusi dan eksklusi khsus. Dalam pengujian efektivitasnya, digunakan 3 indikator yaitu efek protektif MSC-EVs terhadap sel retina, efek pemberian MSC-EVs secara in vivo pasca-iskemik, dan distribusi MSC-EVs dalam cairan vitreous dan perkiraan efek protektif jangka panjang. Secara signifikan memperlihatkan efek protektif, menurunkan faktor inflamasi dan apoptosis sel retina. Kesimpulan: Berdasarkan hasil pengujian secara in vitro dan in vivo MSC-EVs di endositosis oleh sel retinal yang memberikan efek neuroprotektif pada sebelum maupun setelah perawatan, dan efek ini dapat dikembangkan menjadi terapi jangka panjang. Oleh karena itu, dengan menggunakan MSC-EVs dapat menjadi suatu terapi yang menjanjikan dalam penanganan iskemia retina.

Kata kunci : EVs, Iskemia Retina, MSC, Sel Retina 


\section{PENDAHULUAN}

Iskemia retina (IR) adalah penyebab umum gangguan penglihatan dan kebutaan di seluruh dunial dan merupakan penyebab utama kebutaan permanen di negara negara barat yang diperkirakan akan mempengaruhi sekitar 200 juta orang pada tahun 2020. Iskemia Retina ditandai dengan hilangnya dasar pembuluh darah dan hipoksia berkelanjutan disertai proliferasi pembuluh darah masif ke dalam cairan vitreous sehingga menyebabkan putusnya retina dan kebutaan. Iskemia retina (IR) meliputi prematuritas retinopati (ROP), retinopati diabetik (DR), dan degenerasi makula terkait usia (AMD).

Beberapa faktor berkontribusi terhadap patogenesis Iskemia Retina. Namun, stres oksidatif dan proses inflamasi berdiri sebagai faktor utama. Peradangan dan stres oksidan saling terkait erat. Peradangan adalah respons seluler terhadap berbagai faktor (termasuk yang disebabkan oleh stres oksidan) yang mempengaruhi homeostasis dari jaringan, tetapi proses ini juga bertindak sebagai mekanisme pertahanan untuk menjaga keseimbangan fungsi. Sitokin dan kemokin adalah sinyal protein yang melakukan perjalanan ke seluruh tubuh untuk melakukan fungsi spesifik dalam peradangan. Namun, peradangan yangberkelanjutan dapat merusak integritas jaringan ${ }^{1}$.

Terapi yang telah ada dalam menangani iskemia retina yaitu penggunaan suntikan intraokular (misalnya Anti-VEGF), antikoagulan, dan laser. Namun, terapi ini hanya efektif dalam beberapa kasus iskemia retina saja dan hanya efektif bila diberikan lebih awal sebelum perkembangan penyakit terjadi. Adanya efek imunologis dan onkogenik juga belum bisa dihindarkan dengan penggunaan terapi yang ada.

Melihat masalah tersebut, telah banyak studi berkembang yang diarahkan pada strategi terapi terbaru untuk memungkinkan perbaikan regenerasi jaringan yang terluka dengan meminimalkan konsekuensi imunologis dan onkogenik. Dalam hal ini, terapi sel induk menggunakan Mesenchymal Stem Cell (MSCs) berfungsi sebagai pilihan yang menarik. MSC adalah sel multipoten dengan sifat regeneratif dan imunomodulator. Di sisi lain, terdapat bukti yang menunjukkan bahwa sebagian besar efek MSC bersifat parakrin dan dimediasi oleh Extracellular Vesicles (EV) turunan MSC. Mediator tersebut dapat digunakan sebagai agen biomimetik untuk membantu perlindungan saraf dan regenerasi jaringan. MSC-Evs memberikan keuntungan spesifik yaitu kecenderungan yang lebih rendah untuk memicu respon imun serta ketidakmampuan untuk secara langsung membentuk tumor. Oleh karena itu, MSC-EVs dapat terbukti menjadi sumber yang ideal untuk terapi terbaru dalam mengatasi masalah iskemia retina.

\section{HASIL DAN PEMBAHASAN}

\section{Mesenchymal Stem Cell (MSC)}

MSC (Mesenchymal Stem Cell) adalah sel multipoten dengan sifat regeneratif dan imunomodulator yang dapat digunakan dalam perbaikan jaringan dan penyembuhan luka. MSC dapat memperbaharui diri sendiri, memilki kemampuan multipoten yang dapat diisolasi dari berbagai jaringan. Karakteristik dasar MSC adalah salah satu sel primer yang paling mudah diakses dan dapat diambil dengan mudah dari berbagai jaringan, seperti jaringan adiposa, tali pusat, hati, cairan ketuban, plasenta, pulpa gigi, dan sumber lainnya. Kemudahan isolasi, fungsi biologis khusus, disertai kapasitas yang luas dan telah diterima secara etis, menjadikan MSC ini sebagai pilihan terapi sel dalam uji praklinis dan klinis.

Beberapa penelitian dan uji klinis saat ini sedang dilakukan untuk menguji penggunaan MSC dalam berbagai penyakit seperti cedera medula spinalis, sklerosis 
ganda, alzheimer, sirosis hepatis dan hepatitis, osteoarthritis, infark miokard, penyakit ginjal, radang usus, diabetes melitus, kerusakan kartilago lutut, dan transplantasi organ.

Penggunaan MSC sebagai sel benih rekayasa jaringan dalam berbagai penyakit tersebut diatas disebabkan oleh adanya fungsi biologis yang dimilikinya, diantaranya potensi untuk diferensiasi menjadi beberapa turunan sel mesenkim seperti tulang, lemak, tulang rawan, otot, dan turunan sel non mesenkim seperti neuron, sel glial, dan hepatosit.

Selama dekade terakhir, MSC memiliki kemampuan untuk bermigrasi ke jaringan yang terluka dengan melepaskan sitokin, mediator inflamasi, komponen matriks ekstraseluler, dan protein antimikroba untuk menghasilkan lingkungan mikro yang sesuai dalam perbaikan jaringan. Dalam model cedera kornea dan retina, penerapan MSC pada jaringan yang terluka telah ditunjukkan untuk meningkatkan penyembuhan luka. Selain itu, MSC telah terbukti memiliki spektrum luas dengan kemampuan imunoregulasi yang baik. MSC memiliki efek neuroprotektif yang dapat berubah menjadi sel-sel saraf dan mengeluarkan berbagai neurotrofik dan anti-inflamasi.

\section{Extracellular Vesicles (EV)}

Setiap sel dapat mengeluarkan Extracellular Vesicles (EV) untuk berkomunikasi dengan sel lainnya. Hal ini telah dibuktikan oleh Raposo, G.dkk bahwa sel B yang mengeluarkan EV dapat menginduksi respon sel T20. Media komunikasi ini dapat membawa molekul bioaktif dan informasi genetic yang fungsinya mencerminkan sel induknya.

Beberapa studi telah membuktikan adanya mRNA dan non-coding RNA seperti miRNA dalam EV yang akan dibawa menuju sel target. Vesikel ini berinteraksi dengan sel target dengan tiga mekanisme, yaitu terikat ke reseptor di permukaan sel untuk merangsang kaskade persinyalan, internalisasi melalui endositosis, fagositosis, makropinositosis, atau menyatu dengan sel dan mengirimkan secara langsung material tersebut ke membran sitoplasma/sitosol.

Extracellular Vesicles ini terdiri atas membran lipid bilayer dan inti cair sehingga memungkinkan pembawaan obat yang bersifat hidrofilik maupun hidrofobik. Selain kemampuannya melewati sawar darah otak, vesikel ini juga dapat melindungi material yang dibawanya. Vesikel ini berpotensi mengantarkan material tersebut ke sel target secara spesifik, karena pada proses pengantarannya melibatkan protein pada permukaaan vesikel itu sendiri dan protein pada sel target secara spesifik. Ditambah lagi dengan pembuktian secara in vitro dan in vivo bahwa $\mathrm{EV}$ dapat mengurangi kematian sel saraf akibat hipoksia, merangsang pertumbuhan akson, memiliki sifat antiinflamasi, serta berperan sebagai immunomodulator. Dengan kemampuan ini maka EV dapat digunakan sebagai pembawa terapi yang menjanjikan.

\section{Mesenchymal Stem Cell-Derived Extracellular Vesicle (MSC-EVs)}

Dari banyaknya kelebihan yang dimiliki oleh MSC, pemanfaatannya hingga saat ini masih dibatasi karena memiliki integrasi sel yang rendah serta kemungkinan pertumbuhan yang 5 menyimpang. Sehingga dibutuhkan bentuk khusus dalam penghantarannya dan meningkatkan kerja dari MSC ini. Untuk mendukung hal tersebut, dari berbagai penelitian beberapa tahun terakhir, ditemukan bahwa efek dari MSC ini bersifat parakrin dan dimediasi oleh Extracellular Vesicles.

Oleh karena itu, dipikirkan potensi regeneratif dari Mesenchymal Stem Cell yang dibawa dalam bentuk Extracellular Vesicles (MSC-EVs) terhadap jaringan lunak maupun jaringan keras. Extracellular Vesicles ini akan berintegrasi dan bepenetrasi sekaligus menjadi agen pembawa yang bersifat biomimetik 
sehingga tidak di serang oleh sistem imun tubuh. Efek lain dari Extracellular Vesicles ini adalah ditemukan dapat mengurangi kematian sel saraf setelah hipoksia/ iskemia secara in vitro dan in vivo, merangsang pertumbuhan akson, immunomodulator dan sekaligus bersifat anti-inflamasi. Sehingga, dengan menggunakan MSC-EVs ini, dapat bersinergis dalam mengurangi cedera yang disebabkan oleh hipoksia dan iskemia di retina.

\section{Penggunaan MSC-EVs dalam berbagai penyakit}

Beberapa tahun terakhir, MSCEVs sebagai pembawa terapi dalam berbagai penyakit kini mulai dikembangkan. Beberapa penelitian telah dilakukan secara in vivo atau dengan menggunakan hewan coba. Kebanyakan MSC-EVs dimasukkan secara intravena dan intraperitoneal. Penyakit yang sedang diteliti ialah penyakit gagal ginjal akut, infark miokard akut, gagal hati akut, dan cedera otak traumatik ${ }^{41}$.

Pada beberapa hewan coba dengan penyakit yang berbeda, MSCEVs menunjukkan efek yang sama yaitu penekanan sitokin proinflamasi dan peningkatan sitokin antiinflamasi, serta penurunan apoptosis sel dan fibrosis. Adapun efek spesifik yang dihasilkan diantaranya pada model gagal ginjal akut yaitu menekan stres oksidatif yang diinduksi oleh penyakit tersebut. Kemudian, pada cedera otak traumatik dihasilkan efek neuroprotektif jangka panjang, dan pada model infark miokard akut terjadi peningkatan proliferasi sel dan penurunan apoptosis sel, sedangkan pada model gagal hati akut, MSC-EVs ini mengurangi stres oksidatif dan melakukan perbaikan fungsi pada hati tersebut ${ }^{41}$.

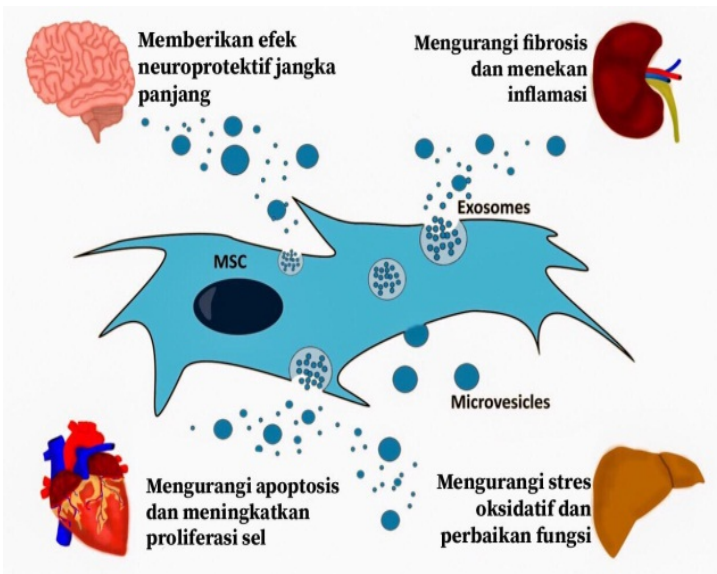

Gambar 1. Gambaran umum kerja MSCEVs dalam berbagai penyakit

\section{Pengolahan MSC-EVs dan Karakteristiknya terhadap sel retina}

Sel mesenkim yang digunakan dalam pembuatan MSC-EVs ini adalah turunan dari Human Mesenchymal Stem Cell (hMSC) yang didapatkan dari berbagai produsen sel kultur seperti American Type Culture Collection (ATCC). Setelah itu kultur sel tersebut diisolasi dan dilakukan berbagai prosedur untuk menghasilkan suspensi Extracellular Vesicles. Sekitar $100 \mu 1$ suspensi di dapatkan dari 1 juta sel kultur yang selanjutnya diverifikasi dengan memeriksa kandungan RNA serta proteinnya.

MSC-EVs yang didapatkan ini terlihat berbentuk seperti lonceng 6 dengan mayoritas ukurannya 50-150 nm berdasarkan hasil pengukuran menggunakan Nanoparticle Tracking Analysis (NTA). Dengan pemeriksaan Western Blot, Vesikel ektraseluler menunjukkan adanya penanda permukaan Exosome yaitu CD81, CD63, CD9, dan HSP70 $\alpha$, yang telah sesuai dengan berbagai penelitian yang juga melakukan pembuatan MSC-EVs ini

Mathew dkk. dalam menguji mekanisme dasar dari endositosis MSCEVs ini melakukan pengujian menggunakan kultur sel retina R28. Didapatkan efisiensi penyerapan yang tinggi dari MSC-EVs oleh sel R28, dan 
terlihat adanya ketergantungan penyerapan tersebut dengan dosis, suhu, dan berbagai jenis ligan. Endositosis dimediasi oleh Caveolin-1 sebagai penanda terhadap Caveolae dan membran lipid serta Clathrin yang akan membentuk lubang endositik ${ }^{2}$.

\section{Efek Protektif MSC-EVs terhadap Sel Retina}

Untuk pengujian efektivitas dari MSCEVs ini digunakan sel retina yang berasal dari tikus Sprague-Dawley yang sebelumnya sudah mengalami stress oksidatif, yaitu sel R28. yang dibuat iskemik secara in vitro. Sel retina di matikan dengan menggunakan teknik Oxygen Glucose Deprivation (OGD). 24 jam sebelum mematikan sel dengan mediasi OGD, beberapa sel diberikan MSC-EVs dan beberapa sel lainnya tidak diberikan. Hasilnya menujukkan bahwa pada sel yang tidak diberikan MSC-EVs terjadi kematian sel $>75 \%$ diakibatkan oleh OGD dan secara signifikan berkurang jika dibandingkan dengan sel yang diberikan MSC-EVs dengan berbagai dosis. Hal ini membuktikan bahwa MSCEVs ini menujukkan efek protektif yang sangat baik terhadap sel Retina dalam masa pra-perawatan.

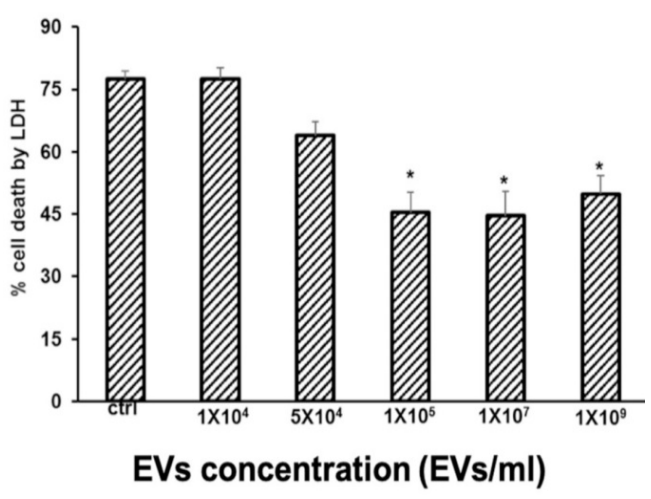

Gambar 2. Efek MSC-EVs dalam berbagai dosis terhadap banyaknya kematian sel yang diinduksi OGD pda sel $\mathrm{R} 28^{2}$

\section{Efek Pemberian MSC-EVs secara in vivo Pasca-Iskemik}

Pengujian secara in vivo dilakukan dengan menggunakan model tikus yang dibius dengan ketamine dan xylazine secara intraperitoneal dan mata tikus dilukai dengan prosedur tertentu sebagai bentuk dari proses iskemiknya. Pada proses iskemik tersebut progres kerusakan sel retina dipengaruhi oleh mediator inflamasi seperti TNF- $\alpha$ dan IL-6, serta apoptosis didukung oleh Caspase-3. Ternyata dengan pemberian MSC-EVs ini dapat menurunkan faktor inflamasi dan apoptosis tersebut secara signifikan yang menandakan bahwa MSC-EVs juga memberikan efek yang sangat baik setelah proses iskemik.

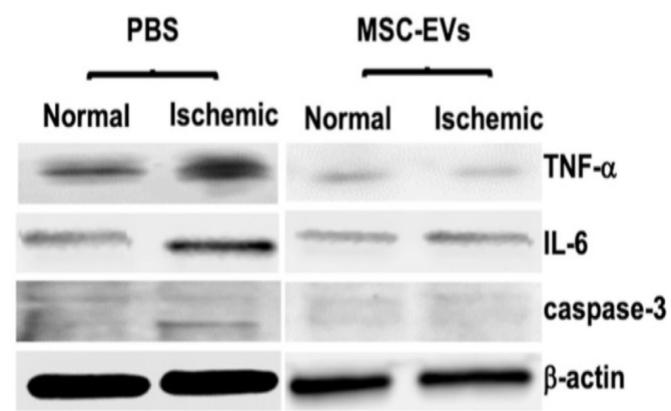

Gambar 3. Representasi Western Blots Untuk TNF- $\alpha$, IL-6, dan Caspase 3 , serta $\beta$-Actin sebagai Loading Control ${ }^{2}$.

\section{Distribusi MSC-EVs dalam cairan Vitreous dan Perkiraan Efek Protektif Jangka Panjang}

Setelah mengamati efek pemberian dari MSC-EVs ini terhadap retina iskemik, pengujian selanjutnya adalah menilai bagaimana distribusi MSC-EVs pada saat setelah diinjeksikan. Untuk menilainya, pada MSC-EVs itu sendiri digunakan Flouroscent untuk melihat tampakan gambarannya melalui Retinal Imaging Microscope. Sebelumnya telah dinilai Free Flouroscent yang diinjeksikan pada intravitreal namun hanya bertahan 48 jam 
dalam cairan vitreous, tapi pada saat Menggunakan MSC-EVs, Flourosensi terlihat hingga 4 minggu kemudian dan hal ini dipastikan sebagai flourosensi dari MSC-EVs itu sendiri. Hal ini menjadi dasar bahwa cairan vitreous dapat berfungsi sebagai reservoir untuk melepaskan EV ke dalam retina dan hal ini dapat menguntungkan untuk memperpanjang $\mathrm{EV}$, meminimalkan jumlah injeksi, dan menghasilkan efek jangka panjang. (lihat gambar 4)

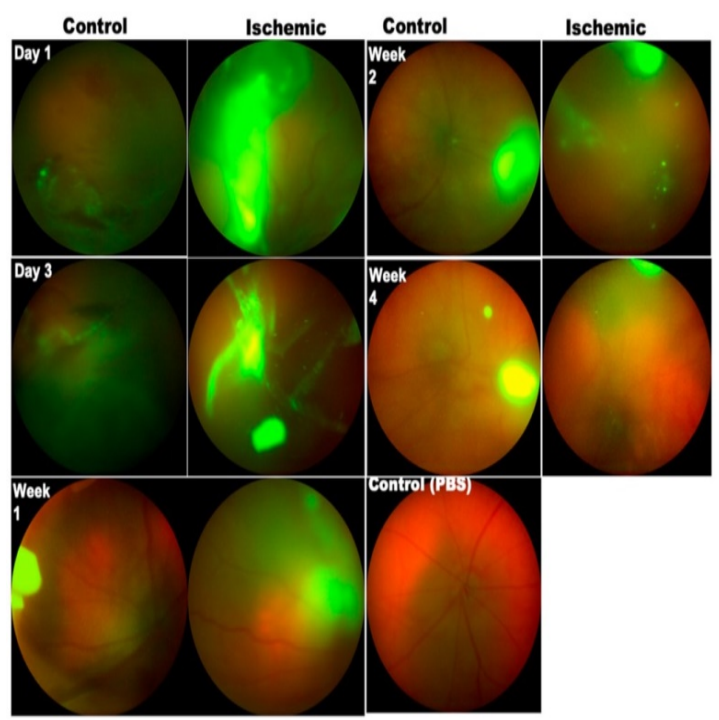

Gambar 4. Pencitraan Secara In Vivo dari MSC-EVs Flourescent hijau yang disuntikan secara intra-vitreal.

\section{KESIMPULAN DAN SARAN}

\section{Kesimpulan}

Pengembangan kerja dari MSC dalam perbaikan sel retina yang mengalami iskemik sekarang bisa diturunkan dalam bentuk partikel biomimmetik yaitu EV. Menggunakan MSC-EVs ternyata memberikan sangat banyak keuntungan dalam transmisi serta efek terapiutik. Berdasarkan hasil pengujian secara in vitro dan in vivo MSC-EVs di endositosis oleh sel retinal yang memberikan efek neuroprotektif pada sebelum maupun setelah perawatan, dan efek ini dapat dikembangkan menjadi terapi jangka panjang. Oleh karena itu, dengan menggunakan MSC-EVs dapat menjadi suatu terapi yang menjanjikan dalam penanganan iskemia retina.

\section{Saran}

Diharapkan penelitian dalam pengembangan MSC-EVs ini dapat terus dilanjutkan hinggka ke pengujian klinis, dan berbagai keterbatasan seperti pengontrolan pelepasan dari EV itu sendiri dapat dilakukan dengan dibuat dalam rekayasa matriks biomimetik.

\section{DAFTAR PUSTAKA}

1. Rivera JC, Dabouz R, Noueihed B, Omri S, Tahiri H, Chemtob S. Review Article Ischemic Retinopathies: Oxidative Stress and Inflammation. 2017;2017.

2. Mathew B, Ravindran S, Liu X, Torres L, Chennakesavalu M, Huang $\mathrm{C}$, et al. Biomaterials Mesenchymal stem cell-derived extracellular vesicles and retinal ischemiareperfusion. Biomaterials [Internet].Elsevier;2019;197(June2018 ):146-60. Available from: https://doi.org/10.1016/j.biomaterials. 2019.01.016

3. P. Sapieha, D. Hamel, Z. Shao et al., "Proliferative retinopathies: angiogenesis that blinds," The International Journal of Biochemistry \& Cell Biology, vol. 42, no. 1, pp. 512, 2010.

4. Y. Wu, L. Tang, and B. Chen, "Oxidative stress: implications for the development of diabetic retinopathy and antioxidant therapeutic perspectives," Oxidative Medicine and Cellular Longevity, vol. 2014, Article ID 752387, 12 pages, 2014.

5. P. X. Shaw, T. Stiles, C. Douglas et al., "Oxidative stress, innate immunity, and age-related macular degeneration," AIMS Molecular Science, vol. 3, no. 2, pp. 196-221, 2016. 
6. F. Semeraro, A. Cancarini, R. dell'Omo, S. Rezzola, M. R. Romano, and C. Costagliola, "Diabetic retinopathy: vascular and inflammatory disease," Journal of Diabetes Research, vol. 2015, Article ID 582060, 16 pages, 2015.

7. S. G. Jarrett and M. E. Boulton, "Consequences of oxidative stress in age-related macular degeneration," Molecular Aspects of Medicine, vol. 33, no. 4, pp. 399-417, 2012

8. Minhas G, Morishita R, Anand A. Preclinical models to investigate retinal ischemia: advances and drawbacks. 2012;3(May):1-7.

9. B. Yu, X. Zhang, X. Li, Exosomes derived from mesenchymal stem cells, Int. J. Mol. Sci. 15 (3) (2014) 41424157.

10. H.J. Kim, J.S. Park, Usage of human mesenchymal stem cells in cell-based therapy: advantages and disadvantages, Dev. Reprod. 21 (1) (2017) 1-10.

11. 11. M. Gnecchi, Z. Zhang, A. Ni, V.J. Dzau, Paracrine mechanisms in adult stem cell

12. Mathew, B.; Ravindran, S.; Liu, X.; Torres, L.; et al. Mesenchymal stemcell derived extracellular vesicles and retinal ischemia-reperfusion. [Internet]. Elsevier; 2019;197(June 2018):146-60. Available from: https://doi.org/10.1016/j.biomaterials. $\underline{2019.01 .016}$

13. Barry, FP and Murphy, JM (2004). Mesenchymal stem cells: clinical applications and biological characterization. Int $\mathrm{J}$ Biochem Cell Biol 36: 568-584

14. Crapnell, K, Blaesius, R, Hastings, A, Lennon, DP, Caplan, AI and Bruder, SP (2013). Growth, differentiation capacity, and function of mesenchymal stem cells expandedin serum-free medium developed via combinatorial screening. Exp Cell Res 319: $1409-1418$
15. http://www.clinicaltrials.

gov; accessed Mei 2019

16. Aurich, H.; Sgodda, M.; Kaltwasser, P.; Vetter, M.; Weise, A.; Liehr, T.; Brulport, M.; Hengstler, J.G.; Dollinger, M.M.; Fleig, W.E.; et al. Hepatocyte differentiation of mesenchymal stem cells from human adipose tissue in vitro promotes hepatic integration in vivo. Gut 2009, 4, 570-581.

17. Matsuse, D.; Kitada, M.; Kohama, M.; Nishikawa, K.; Makinoshima, H.; Wakao, S.; Fujiyoshi, Y.; Heike, T.; Nakahata, T.; Akutsu, H.; et al. Human umbilical cord-derived mesenchymal stromal cells differentiate into functional Schwann cells that sustain peripheral nerve regeneration. J. Neuropathol. Exp. Neurol. 2010, 9, 973-985.

18. Reinshagen, H.; Auw-Haedrich, C.; Sorg, R.V.; Boehringer, D.; Eberwein, P.; Schwartzkopff, J.; Sundmacher, R.; Reinhard, T. Corneal surface reconstruction using adult mesenchymal stem cells in experimental limbal stem cell deficiency in rabbits. Acta Ophthalmol. 2011, 8, 741-748.

19. Johnson, T.V.; Bull, N.D.; Hunt, D.P.; Marina, N.; Tomarev, S.I.; Martin, K.R. Neuroprotective effects of intravitreal mesenchymal stem cell transplantation in experimental glaucoma. Investig. Ophthalmol. Vis. Sci. 2010, 4, 2051-2059.

20. Raposo, G.; Nijman, H.W.; Stoorvogel, W.; Liejendekker, R.; Harding, C.V.; Melief, C.J.; Geuze, H.J. B lymphocytes secrete antigenpresenting vesicles. J. Exp. Med. 1996, 183, 1161-1172. [CrossRef] [PubMed]

21. Valadi H, Ekstrom K, Bossios A, Sjostrand M, Lee JJ, Lotvall JO. Exosome-mediated transfer of mRNAs and microRNAs is a novel mechanism of genetic exchange 
between cells. Nat Cell Biol. 2007;9(6):654-659.

22. Thery C, Zitvogel L, Amigorena S. Exosomes: composition, biogenesis and function. Nat Rev Immunol. 2002;2(8):569-579.

23. Kahlert $\mathrm{C}$, et al. Identification of double-stranded genomic DNA spanning all chromosomes with mutated KRAS and p53 DNA in the serum exosomes of patients with pancreatic cancer. J Biol Chem. 2014;289(7):3869-3875.

24. Ratajczak J, et al. Embryonic stem cell-derived microvesicles reprogram hematopoietic progenitors: evidence for horizontal transfer of mRNA and protein delivery. Leukemia. 2006;20(5):847-856.

25. Maas SLN, Breakefield XO, Weaver AM, Hospital MG. Extracellular vesicles: unique intercellular delivery vehicles. 2018;27(3):172-88.

26. J.M. Pitt, G. Kroemer, L. Zitvogel, Extracellular vesicles: masters of intercellular communication and potential clinical interventions, J. Clin. Investig. 126 (4) (2016) 1139-1143.

27. Lai, RC, Yeo, RW, Tan, KH and Lim, SK (2013). Exosomes for drug delivery - a novel application for the mesenchymal stem cell. Biotechnol Adv 31: 543-551

28. L.A. Mulcahy, R.C. Pink, D.R. Carter, Routes and mechanisms of extracellular ve- sicle uptake, J. Extracell. Vesicles 3 (2014)

28. M.B. Goncalves, T. Malmqvist, E. Clarke, C.J. Hubens, J. Grist, C. Hobbs, D. Trigo, M. Risling, M. Angeria, P. Damberg, T.P. Carlstedt, J.P. Corcoran, Neuronal RARbeta signaling modulates PTEN activity directly in neurons and via exosome transfer in astrocytes to prevent glial scar formation and induce spinal cord re- generation, J. Neurosci. : Official J. Soc. Neurosci. 35 (47) (2015) 15731-15745.
29. B. Zhang, Y. Yin, R.C. Lai, S.K. Lim, Immunotherapeutic potential of extracellular vesicles, Front. Immunol. 5 (2014) 518.

30. T.R. Doeppner, J. Herz, A. Gorgens, J. Schlechter, A.K. Ludwig, S. Radtke, K. de Miroschedji, P.A. Horn, B. Giebel, D.M. Hermann, Extracellular vesicles improve post-stroke neuroregeneration and prevent postischemic immunosuppression, Stem Cell. Trans. Med. 4 (10) (2015) 1131-1143.

31. M. Khan, E. Nickoloff, T. Abramova, J. Johnson, S.K. Verma, P. Krishnamurthy, A.R. Mackie, E. Vaughan, V.N. Garikipati, C. Benedict, V. Ramirez, E. Lambers, A. Ito, E. Gao, S. Misener, T. Luongo, J. Elrod, G. Qin, S.R. Houser, W.J. Koch, R. Kishore, Embryonic stem cell-derived exosomes promote endogenous repair mechanisms and enhance cardiac function following myocardial infarction, Circ. Res. 117 (1) (2015) 52-64.

32. V. Zappulli, K.P. Friis, Z. Fitzpatrick, C.A. Maguire, X.O. Breakefield, Extracellular vesicles and intercellular communication within the nervous system, J. Clin. Investig. 126 (4) (2016) 1198-1207.

33. L.A. Beninson, M. Fleshner, Exosomes: an emerging factor in stress-induced im- munomodulation, Semin. Immunol. 26 (5) (2014) 394401

34. Jarmalavičiūtė A, Pivoriūnas A. Exosomes as a potential novel therapeutic tools against neurodegenerative diseases. Pharmacol Res. 2016 Feb 6. Epub ahead of print. doi: 10.1016/j.phrs.2016.02.002

35. Lener $\mathrm{T}$, et al. Applying extracellular vesicles based therapeutics in clinical trials - an ISEV position paper. J Extracell Vesicles. 2015; 4:30087.doi: 10.3402/jev.v4.30087 26725829] 
36. T.V. Johnson, N.D. Bull, K.R. Martin, Identification of barriers to retinal engraftment of transplanted stem cells, Investig. Ophthalmol. Visual Sci. 51 (2)(2010) 960-970.

37. Y. Yao, J. Huang, Y. Geng, H. Qian, F. Wang, X. Liu, M. Shang, S. Nie, N. Liu, X. Du, J. Dong, C. Ma, Paracrine action of mesenchymal stem cells revealed by single cell gene profiling in infarcted murine hearts, PLoS One 10 (6) (2015) e0129164

38. R. Narayanan, C.C. Huang, S. Ravindran, Hijacking the cellular mail: exosome mediated differentiation of mesenchymal stem cells, Stem Cell. Int. 2016 (2016) 3808674.

39. M.B. Goncalves, T. Malmqvist, E. Clarke, C.J. Hubens, J. Grist, C. Hobbs, D. Trigo, M. Risling, M. Angeria, P. Damberg, T.P. Carlstedt, J.P. Corcoran, Neuronal RARbeta signaling modulates PTEN activity directly in neurons and via exosome transfer in astrocytes to prevent glial scar formation and induce spinal cord regeneration, J. Neurosci. : Official J. Soc. Neurosci. 35 (47) (2015) 1573115745

40. Börger V, Bremer M, Ferrer-tur R, Gockeln L, Stambouli O. Mesenchymal Stem / Stromal CellDerived Extracellular Vesicles and Their Potential as Novel Immunomodulatory Therapeutic Agents. 2017;

41. R. Narayanan, C.C. Huang, S. Ravindran, Hijacking the cellular mail: exosome mediated differentiation of mesenchymal stem cells, Stem Cell. Int. 2016 (2016) 3808674.

42. K. McNicholas, M.Z. Michael, Immuno-characterization of exosomes using nanoparticle tracking analysis, Methods Mol. Biol. 1545 (2017) 3542. 